\title{
EXPLOITATION OF PALAEONTOLOGICAL AND HYDROGEOLOGICAL FEATURES FOR GEOTOURISM IN MESOPOTAMIA - OINOI, KASTORIA, NORTHERN GREECE
}

\author{
Kazakis N., Syrides G. and Voudouris K. \\ Aristotle University of Thessaloniki, School of Geology, 54124, Thessaloniki, Greece, \\ kazakis@geo.auth.gr,syrides@geo.auth.gr,kvoudour@geo.auth.gr
}

\begin{abstract}
The aim of this study is to reveal the geological, paleontological and hydrogeological features of the surrounding area of Oinoi in municipality of Kastoria, Northern Greece. These features can attract visitors and develop geotourism in the area. Fossil mollusk shells (Pectinidae family, Pecten and Flabellipecten) were recognized in three fossiliferous sites. Additionally, the palaeontological features are supplemented by impressive alternations of sedimentary strata, cavities, springs, small natural waterfalls and lakes as well as a small dam. Three routes (the longest is $12.3 \mathrm{Km}$ ) were defined for the promotion of these features. The routes are suitable for walking, jogging, mountain biking, climbing, for students, elder people and adults. This is a preliminary approach, since further research in the wider area is needed, in order to include more existing natural features, as well as to create a comprehensive management plan and define the criteria for the proposal of the site as a Geopark. Keywords: Geotourism, Fossils, Sedimentary strata, Natural Cavities, Waterfall.
\end{abstract}

\section{Пєрí $\eta \psi \eta$}

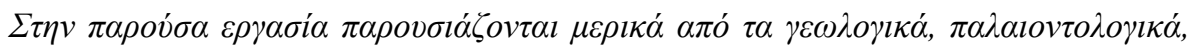

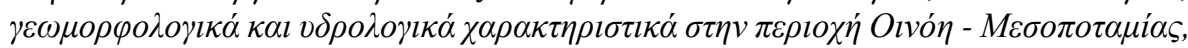

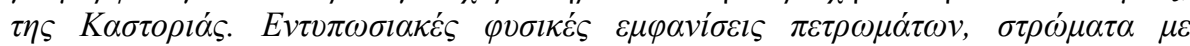

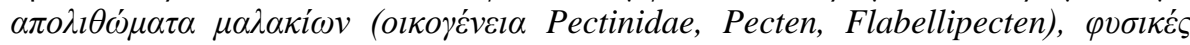

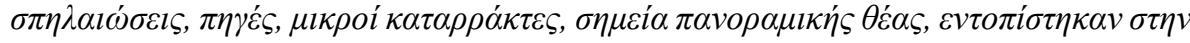

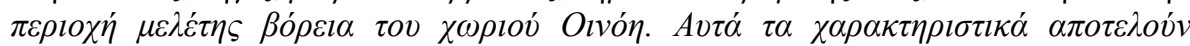

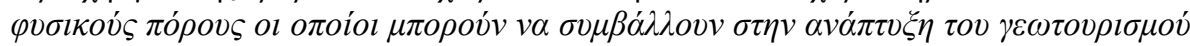

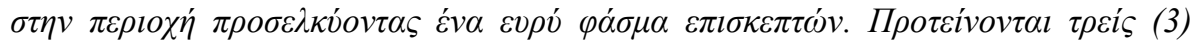

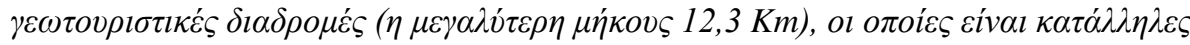

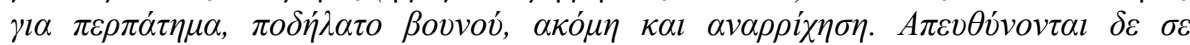

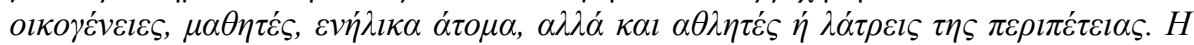

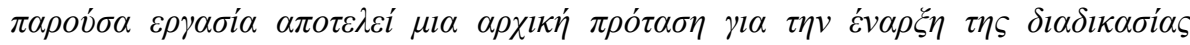

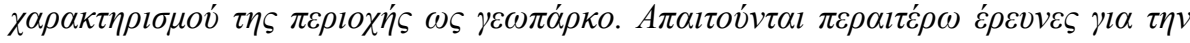

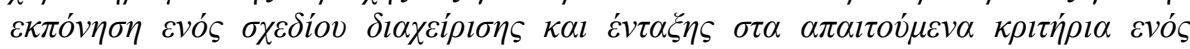

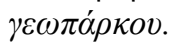

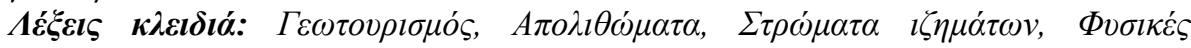

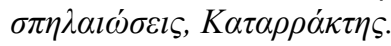




\section{Introduction}

Geotourism constitutes a form of nature-based tourism where noticeable geomorphological and geological features attract people so as to learn about and admire (Dowling, 2011). Moreover, it is a unique conglomeration of tourism, economic, educational and cultural elements and human interactions with local geology which contributes to the geological and field knowledge (Fung and Jim, 2015a). According to Farsani et al. (2014) geotourism ensures an economic and environmental sustainability, geological education and reinforcement of local livelihood and culture. The Global Network of National Geoparks (GGN) prerequisite these visions in the guidelines for the application for membership (Fung and Jim, 2015b). According to the criteria developed by UNESCO, a geopark should have the following characteristics (Vdovets et al., 2010):

- well-defined limits and an area large enough to favour the local economy and culture

- comprehensive geological know-ledge of the area

- substantial quantity of visitor-accessible geosites of special scientific importance

- aesthetic importance

- non-geological natural, archeological, historical or, cultural valuables of interest for tourists

- well developed infrastructure.

Additionally, the Nations Education, Scientific and Cultural Organization (UNESCO) support the growing number of geoparks acknowledging their importance (GGN, 2010) and their amplification to maintain the geoheritage in a specific region.

Greece has an exuberant geological heritage with a variety of rocks, minerals, fossils, soils and landforms. Actually, there are five recognized Geoparks in Greece which are (Zouros, 2004): the Mt. Psiloreitis Natural Park, the Mt Chelmos-Vouraikos National Park, the Vikos-Aoos National Park, the Agios Nikolaos Petrified Forest in Laconia and the Lesvos Petrified Forest.

The aim of this study is to illustrate the natural features of the surrounding area of Oinoi in Mesopotamia municipality, Northern Greece. Geological, palaeontological and hydrogeological features were studied in order to demonstrate attractive routes for geotourism.

\section{Study site}

The study area is located in the Municipal Region of Mesopotamia, in Prefecture of Western Macedonia Northern Greece (Figure 1). It is a part of the local community of Oinoi which covers an area of $27 \mathrm{Km}^{2}$, has a mean altitude of $861 \mathrm{~m}$ and mean slope of $18.6 \%$. The maximum elevation is $1083 \mathrm{~m}$ and the minimum is $691 \mathrm{~m}$.

According to census data of the Hellenic Statistical Authority (2011), the permanent population is about 475. The climate is intermediate Mediterranean to Continental with dry summers and wetcold winters with heavy rains and snow. The area's mean annual temperature and precipitation values are $12.6^{\circ} \mathrm{C}$ and $591 \mathrm{~mm}$ (Kastoria station), respectively. Agriculture constitutes the primary economic activity of the area and the main crops are cereals, corn, vegetables and wine grapes. The water demands of the study area are met with the exploitation of groundwater, surface water and springs. The main aquifers in the region are developed in the alluvial and fluvial deposits as well as in Neogene formations (sandstones and conglomerates). The yield of the boreholes vary between 25 to $40 \mathrm{~m}^{3} / \mathrm{h}$, whereas the depth of groundwater range from 13 to $24 \mathrm{~m}$. The water type of groundwater is $\mathrm{Ca}-\mathrm{Mg}-\mathrm{HCO}_{3}$.

The study site is mainly comprised by Neogene sediments of the Mesohellenic trench, as well as by younger quaternary sediments (Figure 1). Three Formations of the Mesohellenic trench expose in the area of Oinoi: Tsotili Fm, Omorphoclissia Fm and Pentalofos Fm.

Omorphoclissia Fm consists of alternations of sandstones and marls, and is located in the western part of the study area. Tsotili Fm consists of a thick $(\sim 2 \mathrm{Km})$ succession of conglomerates, 
sandstones, marls and clastic limestones, and is located in the northern part of the study area. Pentalofos Fm consisting of sandstones is located in the north-west part of the study area.

Quaternary sediments comprise alluvial deposits, river terraces and fluvial-lacustrine deposits that were deposited along the valleys of the area of Oinoi village. The alluvial deposits consist of sand and gravels, whereas the river terraces and the fluvial-lacustrine deposits comprises of loose conglomerates, blue to greenish clays, sands, loose sandstones, conglomerates and red clays in the upper parts.
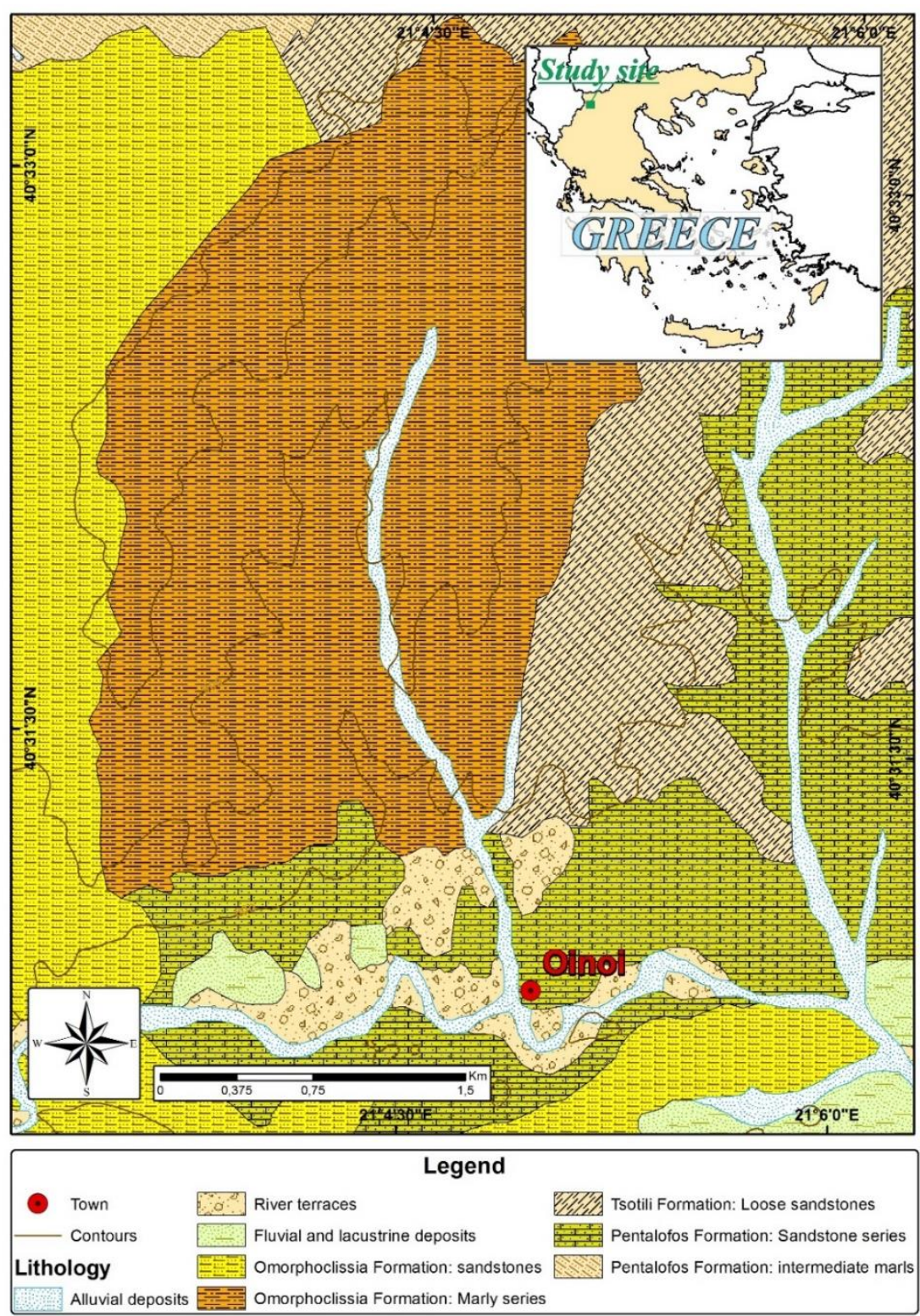

Figure 1 - Geological map of the study area. 


\section{Materials and Methods}

For the implementation of this study were used the geological map (1:50,000 scale) sheet KoritsaMesopotamia (IGME, 1990) and the corresponding topographic maps of Hellenic Military Geographical Service (sheets Koritsa and Mesopotamia). The geological formations and contours were digitized with the GIS software ArcGIS 10.3 and the Digital Elevation Model of the area was produced with resolution of $20 \mathrm{~m}$.

An extensive geological field work and mapping was performed in the study area and the locations of the geological, paleontological and hydrogeological features were marked with a GPS. The stratigraphic columns of the fossil locations were created and digitized. The geological, paleontological and hydrogeological features were assembled and combined so as to develop attractive routes for geotourism in the mountainous part of Oinoi.

\section{Results and discussion}

The surrounding area of Oinoi village has a remarkable geological heritage with paleontological, $\mathrm{m}$ orphological, geological and hydrogeological features and can be characterized as a small Geopark. In figure 2 are shown photos of some features which can attract geo-tourists or tourists who want $\mathrm{t}$ o explore nature. The fossiliferous locations (Figure $1 \mathrm{~A}, \mathrm{~B}, \mathrm{C}$ ) are accessible and the fossils are easily visible. In addition, the local community have developed a small museum exhibiting selected fossils (Figure 1, H). The photo in Figure 1C, illustrates a natural cavity which is a result of the geological structure of the area due to alternating successive beds of sandstones, marls and clay. The cavities have been developed due to the selective erosion of marls and clays in contrast to the sandstone. Hydrology of the area reveal many small springs and small tributaries with permanent flow $\left(\sim 55 \mathrm{~m}^{3} / \mathrm{h}\right)$ that create natural small waterfalls and lakes due to the variable terrain (Figure $1 \mathrm{E}$, F). A small dam which was founded on the sandstones creates an attractive picturesque landscape (Figure 1, D).

The aforementioned features can create exuberant and interesting ambulatory routes for visitors. M oreover, this study has revealed three well accessed fossiliferous locations which can also be used for educational purposes.

The first fossiliferous site is situated $1400 \mathrm{~m}$ north of the Oinoi village into a torrent valley (Figure 2, A and Figure 4). It's about $40 \mathrm{~m}$ from the unpaved road and it is easily accessible. A $20 \mathrm{~m}$ thick continuous succession of sandstone beds, $2-5 \mathrm{~m}$ thick, alternating with more fine (silt-clay) and coarse grained (conglomerate) beds are exposed along the torrent valley. The stratigraphic column of the fossiliferous site 1 is presented in Figure 3, A.

A thick ( $5 \mathrm{~m}$ ) bed of fine grained sandstone contains numerous fossil mollusks at the lowermost $2 \mathrm{~m}$ part. The fauna includes Pectinidae bivalves; the genera Pecten and Flabellipecten were recognized. Fossils appear as casts due to dissolution of the initial calcite shells. The casts are filled by iron (limonite) and manganese oxides (Figure 2, G, H) resulting to impressive colorations (yellow, ochre, light brown, dark brown, blackish). In the upper horizons of the section the silty layers contain plant remnants. Scattered badly preserved leafs and small stems were found on the exposed eroded rock surface. Further work (an excavation) is needed to uncover well preserved specimens.

The second fossil site is situated $1 \mathrm{Km}$ north-west of the Oinoi village (Figure 4). Fine grained san dstones containing fossil mollusks are exposed (Fig. 2, B) and it's stratigraphic column is shown in Figure 3, B. The fauna includes mollusks of the Pectinidae family preserving their shells. Fossils appear as well cemented and compacted shells that form stiff masses, not allowing further determination.

In the third locality, the fossils and strata are similar to the first site. However, the exposure of the fossils is small in comparison with the first location, whereas it's distance from the village of Oinoi is $600 \mathrm{~m}$ to the north. 
Except the above three fossiliferous sites, many other small occurrences containing few well observed fossils, or numerous small undetermined fossils were located scattered along the area (Figure 4). The fossiliferous locations in conjunction with the geological, morphological and hydro geological features were ranked and grouped and therefore three routes were defined and proposed for geotourism in the study site. The three routes are shown in Figure 4.

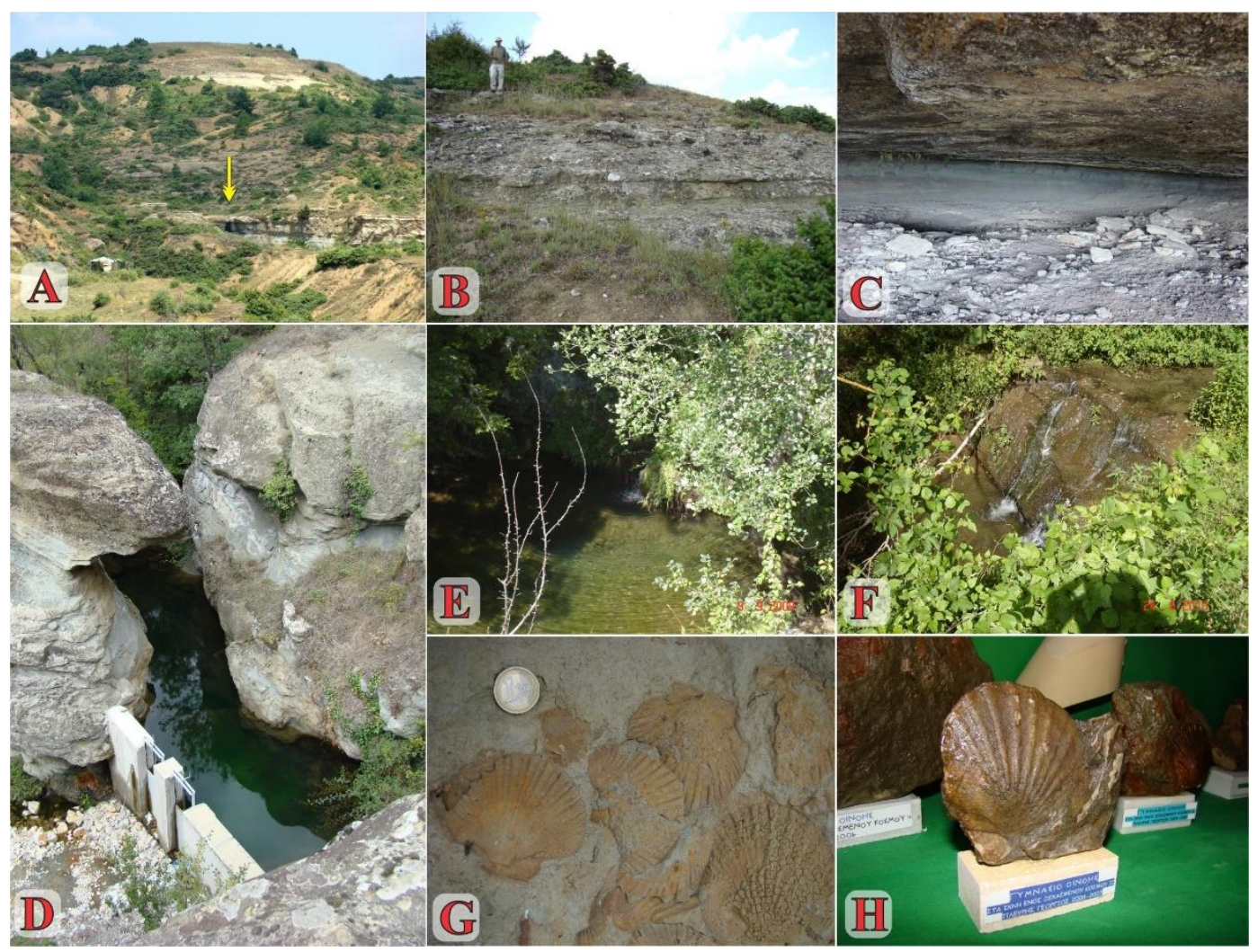

Figure 2 - Paleontological, geological and hydrogeological structures in the study area. A) First fossil location, B) Second fossil location, C) Interior of a natural cavity, D) Small dam, E) Small lake with waterfall, F) Small waterfall, G) Fossils in the field, and H) Exhibits of the small museum.

Route 1. The first route constitutes the larger of the three routes with length up to $12.3 \mathrm{Km}$. The route is on the dirt road which it begins from the Oinoi village with $700 \mathrm{~m}$ elevation and follows the watershed line of Milios tributary. Following the route the first fossiliferous location is found after 1400 meters from the village. The highest elevation of the route is $1080 \mathrm{~m}$ in Flatsata site, with the small church of Agia Marina, and then the downhill part of the route follows. Along the route smaller appearances of fossils, natural cavities and impressive alternations of sandstones, marls and clay can be observed and many of them can be visited. Moreover, there are resting points (e.g. the church of Agia Marina) in which the visitors can enjoy panoramic view of the natural landscape, and rest. In the last part of route 1 the visitors can approach to the fossiliferous site 2 .

Route 2. The length of this route is $4.3 \mathrm{Km}$ and is shown in Figure 4 with green color. This route is the most rough and is connected with route 1 . The visitor can found smaller occurrences of fossils, natural cavities and alternations of the geological formations. This route is proposed for persons with good physical condition that want more difficult trails, and is not appropriate for families and elder people. Climbing skills and excellent physical condition is needed. 
Route 3. Actually is the smaller proposed route with length up to $1 \mathrm{Km}$. The route follows a small dirt road which precesses into a trail. The route is near to the Milios tributary and encounters the aforementioned dam. Similarly to route 2, the visitor can found fossils along the route and approach to the fossiliferous location 3. Impressive alternations of geological strata can be seen as well as small lakes and waterfalls, whereas the visitor can find small springs following the tributary after the dam.

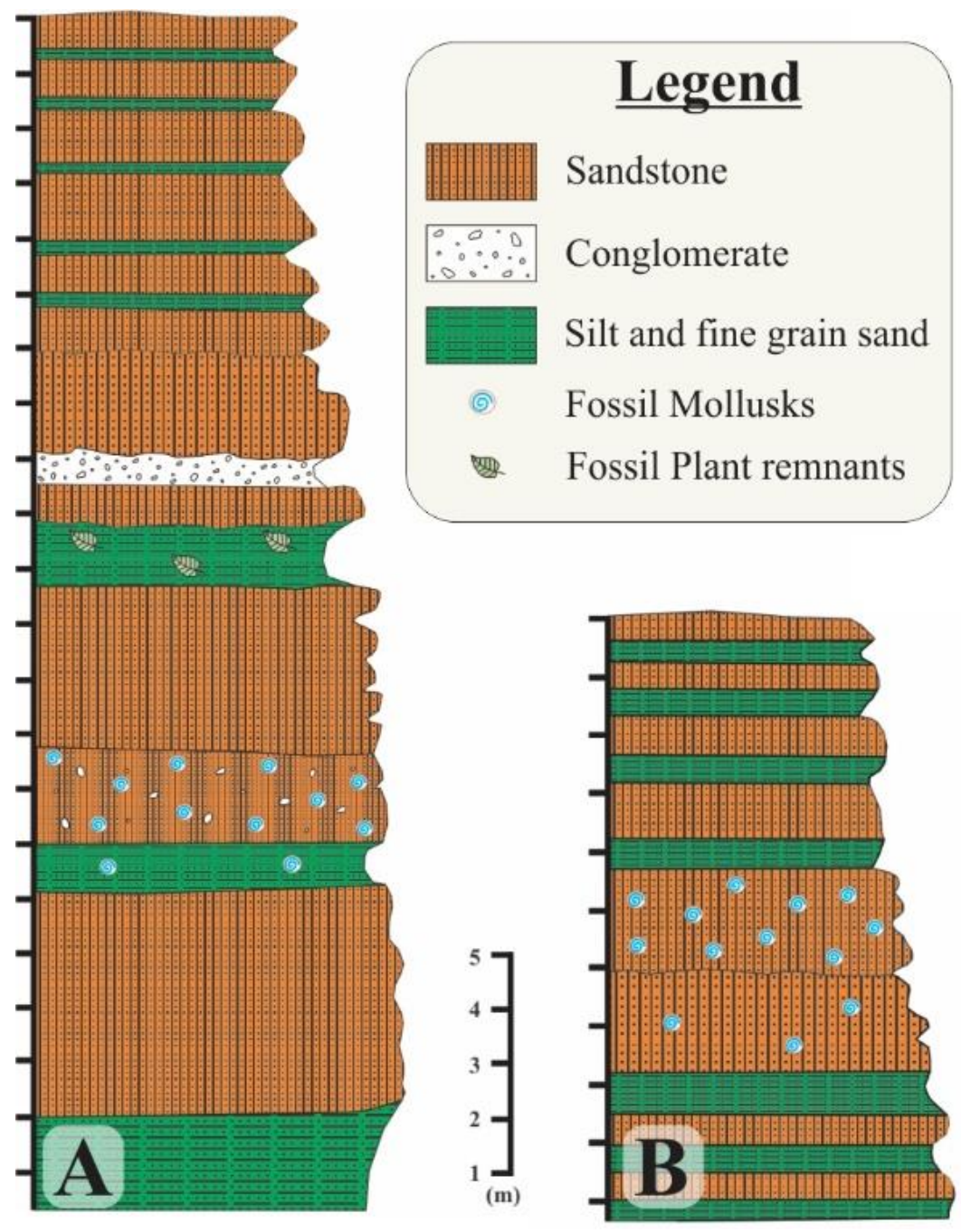

Figure 3 - Stratigraphic columns of the fossiliferous sites. 


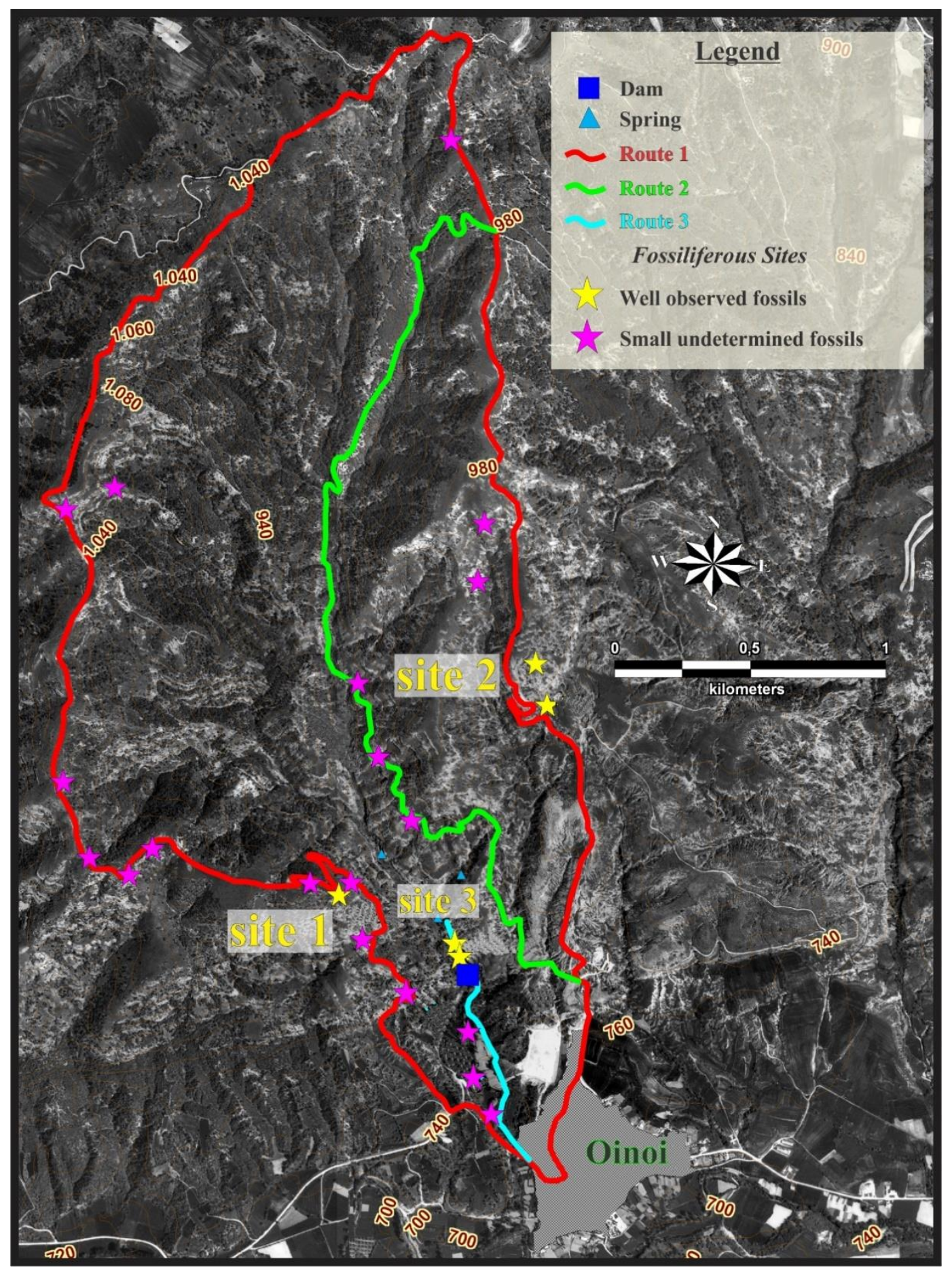

Figure 4 - Map with the proposed routes in the surroundings of Oinoi.

The proposed routes are attractive for a variety of tourists such as naturists, families, students and adventure lovers of all ages. In addition, the routes highlight a part of the geological heritage of the wider area. The development of this site for touristic proposes would significantly benefits local economy as well as the diffusion of the geological knowledge. However, it is essential the decision 
makers and all the stakeholders to develop a management plan and proceed to the development of essential infrastructure in the site.

Moreover, this study can be expanded in the wider area in order to emerge more geological features. Additionally, a future research can examine if the wider area can be included in the Global Geopark Network. According the Guidelines and Criteria for National Geoparks seeking UNESCO's assistance to join the Global Geoparks Network 2010.

The criteria are:

The Size and setting. The area's boundary should be clearly defined. The area must be large enough for it to serve local economic and cultural development. The Geopark should display though a range of sites of international, regional and/or national importance, a region's geological history, and the events and processes that formed it.

Management and local involvement. An established management system and programme of implementation is prerequisite. For example the geological and non-geological features inside the Geopark area must be accessible to visitors, linked to one another and safeguarded based on a plan.

Economic development. One of the main strategic objectives of a Geopark is to stimulate economic activity within the framework of sustainable development. For instance, the creation of innovative local enterprises, cottage industries, small business, initiate high quality training courses and new jobs by generating new sources of revenue.

Education. A Geopark must provide and organize support, tools, and activities to communicate geoscientific knowledge and environmental and cultural concepts to the public. Therefore, interpretive and educational centres, trails, museums, guided tours, popular literature and maps, and modern communication media should be established in the wider area.

Protection and conservation. The authorities responsible for the Geopark must ensure its protection in accordance with local traditions and legislative obligations. The Geopark shall contribute to the conservation of significant geological features such as: fossils, landforms and landscapes, minerals and mineral resources and representative rocks. This features should provide information on various geoscientific disciplines such as: hydrogeology, engineering geology, hydrology, geomorphology, palaeontology, petrology, sedimentology, speleology, stratigraphy etc.

The Global Network. The Global Geopark Network is under the umbrella of UNESCO and through cooperation with the global network partners, important local, and national, geological sites gain worldwide recognition and benefits. The exchange of knowledge and expertise, experience and staff between other Geoparks is encouraged.

From the aforementioned criteria it is clear that the studied area could not be included in the Global Geoparks Network. However, a comprehensive research in the wider area in combination with a strategically plan of the local authorities could render this aspect possible in the future.

\section{Conclusions}

This study focused in the surrounding area of Oinoi village in the municipality of Kastoria, Northern Greece. It has revealed the geological heritage of the area including paleontological, hydrogeological, geomorphological and sedimentological features.

Fossil molluscs (Pectinids, Pecten and Flabellipecten) were recognized in three fossiliferous sites; as well as many small occurrences of undetermined fossils were located along the area. Additionally, the palaeontological features are supplemented by impressive alternations of sediments, cavities, small natural waterfall and lakes and a small dam. All these futures are included in three proposed routes suitable for geotourism. The largest is up to $12.3 \mathrm{Km}$ and the visitor can reach in elevations 
up to $1080 \mathrm{~m}$. The three routes can be used for walk, jogging and climbing and are suitable for all ages.

A future research in the wider area with a comprehensive management plan is essential in order to enrich the existing features and define the criteria for the insertion of the site to the Global Geopark Network.

\section{Acknowledgement}

This research was carried out within the framework of the scientific Research project "GeologicalHydrogeological-Paleontological research of the Municipality of Mesopotamia" and has been funded by the municipality of Mesopotamia.

\section{References}

Dowling, R.K., 2011. Geotourism's global growth, Geoheritage, 3, 1-13.

Farsani, N.T., Coelho, C., Costa, C.M.M. and Amrikazemi, A., 2014. Geo-knowledge management and geoconservation via geoparks and geotourism, Geoheritage, 6, 185-192.

Fung, C.K.W. and Jim, C.Y., 2015a. Segmentation by motivation of Hong Kong Global Geopark visitors in relation to sustainable nature-based tourism, International Journal of Sustainable Development and World Ecology, 22(1), 76-88.

Fung, C.K.W. and Jim, C.Y., 2015b. Unraveling Hong Kong Geopark experience with visitoremployed photography method, Applied Geography, 62, 301-313.

GGN, 2010. Guidelines and criteria for national geoparks seeking UNESCO's assistance to join the Global Geoparks Network, Beijing, Global Geoparks Network.

IGME, Institute of Geology and Mineral Exploration, 1990. Geologic map of Greece (scale 1:50,000), Sheet Koritsa-Mesopotamia.

UNESCO, 2010. Guidelines and Criteria for National Geoparks seeking UNESCO's assistance to join the Global Geoparks Network.

Vdovets, M.S., Silantiev, V.V. and Mozzherin, V.V., 2010. A National Geopark in the republic of Tatarstan (Russia): A feasibility study, Geoheritage, 2, 25-37.

Zouros, N., 2004. The European Geoparks Network: geological heritage protection and local development, Episodes, 27(3), 165-171. 